\title{
Betegpreferenciák az egészségügyi célú internethasználatban
}

\author{
Varga Zsuzsa dr. - Horváth Tamás dr. \\ ENT House Budapest rendelő, Budapest
}

\begin{abstract}
Bevezetés: Az internet mélyebb implementálása az egészségügybe több szempontból is javítja az ellátást, de ehhez meg kell ismerni a betegek preferenciáit az internetalapú infokommunikációs eszközök egészségügyi célú használatát illetően.

Célkitüzés: A betegek egészségügyi célú internethasználatára vonatkozó szokásainak, attitűdjének megismerését tűztük ki célul.

Módszer: Kérdőíves felmérést végeztünk 2016. október és 2017. április között fül-orr-gégészeti magánrendelőnkben, vizsgálaton megjelent betegek körében.

Eredmények: 208 kérdőívet elemeztünk. A betegek nagy része naponta használja az internetet, elsősorban mobileszközökön. Szinte mindegyikük keresett már egészségügyi információt online, 19\%-uk rendszeresen. 53\%-uk elégedett a tartalommal, és nyitottak az orvos által javasolt weboldalak irányában. A betegek 32\%-a kommunikált már online orvosával, és 93\%-uk elégedett volt ezzel a kapcsolati formával. A betegek 8\%-a használ rendszeresen okostelefonon egészségügyi alkalmazást, 6\%-uk egyéb internetalapú egészségügyi adatrögzítő eszközt. A páciensek 60\%-a választott már online információk alapján kezelőorvost, 17\%-uk pedig rendszeresen így keres doktort. A válaszadók $82 \%$-a még nem osztott meg egészségével kapcsolatos információt a világhálón.

Következtetések: A betegek nagy arányban az internetről tájékozódnak az egészségükkel kapcsolatban. Az ott fellelhető információ minőségével nem teljesen elégedettek, viszont orvosuktól elfogadnák, ha ajánlana honlapokat. Növelné a betegmegelégedettséget, akár a kezelés hatékonyságát is, ha a betegek online kommunikálhatnának orvosukkal. Az egészségügyi jellegü okostelefon-alkalmazások, digitális eszközök terén nem érezni igazi áttörést, az elvi igény is mérsékelt, és az online betegközösségek sem kifejezetten népszerúek. Viszont az orvostársadalomnak szembe kell néznie a ténnyel, hogy az orvosválasztás egyre nagyobb arányban a világhálón fellelhető információn alapul.
\end{abstract}

Orv Hetil. 2018; 159(51): 2175-2182.

Kulcsszavak: internethasználat, online egészségügyi információ, okoseszköz, kommunikáció

\section{Patients' preferences for health-related use of Internet}

Introduction: More sophisticated implementation of the Internet in healthcare improves medical services innumerably. To better understand the patients' preferences for health-related use of Internet is warranted.

Aim: Our aim was to determine the patients' health-related Internet use.

Method: Patients attending our private clinic between October 2016 and April 2017 were surveyed.

Results: 208 questionnaires have been evaluated. Most patients use Internet daily, primarily on mobiles. The majority have already searched for health-related information online, 19\% do regularly. 53\% are satisfied with online contents and open to websites recommended by physicians. $32 \%$ of patients have already communicated with doctors online and $93 \%$ are satisfied doing so. $8 \%$ of patients use health-related smartphone applications regularly, $6 \%$ use other Internet-based health-monitoring devices. $60 \%$ of patients have already chosen a physician based on web information, while $17 \%$ do regularly. $82 \%$ of respondents have not yet shared health-related information on the Internet. Conclusions: The Internet is widely used by patients seeking information about their health, yet they are dissatisfied with the quality. Many patients are open to recommendations offered by physicians regarding sources of online information. Online communication between physician and patient might increase patient satisfaction. There is no breakthrough in the use of health-related websites, mobile apps or devices in Hungary. The demand for such service could be considered moderate. Additionally, online patient forums are not specifically popular. The medical society in Hungary should accept that physician selection by patients depends more increasingly upon information made available online.

Keywords: Internet use, online health information, smartphone, communication

Varga Zs, Horváth T. [Patients' preferences for health-related use of Internet]. Orv hetil. 2018; 159(51): $2175-2182$.

(Beérkezett: 2018. június 4.; elfogadva: 2018. július 7.) 
Az internetet és a netalapú eszközöket sokféleképpen lehet implementálni az egészségügyi ellátásba. Idetartozik a kétirányú kommunikáció (orvos-beteg; beteg-beteg; orvos-orvos), a széles körü, nyilvános felvilágosítás, illetve a diagnosztikus, utánkövetési vagy terápiás célú adatátvitel (eszköz-beteg; eszköz-orvos; orvos-eszköz). Korábban a telemedicina kifejezést használták erre, amely elsősorban az internetalapú távdiagnosztikát és monitorozást takarta. Újabban a telehealth elnevezés kezd elterjedni, amely ugyanez kibővítve felvilágosítással, prevencióval, terápiával, kifejezetten a mobileszközökre fókuszálva pedig az m-health (mobile-health) kifejezést illik használni [1]. A definíciók változása is azt jelzi, hogy az internet egyre dominánsabb szerephez jut az egészségügyben, a netalapú orvosi technológiák és formabontó innovációk alkalmazása fokozatosan elválaszthatatlanná vált a legmagasabb szintű ellátástól $[2,3]$. Az Európai Unió egyik célkitűzése is az, hogy az internet adta technológiai lehetőségeket mélyebben implementálja a tagállamok egészségügyébe [4], mivel számos aspektusból bebizonyították, hogy az javítja az ellátást. Az online infokommunikációs eszközök használata csökkenti a felesleges vizsgálatok és személyes találkozások számát [5], csökkenti a mortalitást, a kórházi kezelés idejét és költségét $[6,7]$, növeli az ellátás minőségét, a betegmegelégedettséget, s ezáltal indirekt az egészségügybe vetett bizalmat is kedvezóen befolyásolja $[8,9]$.

$\mathrm{Az}$ internet mélyebb beépülését az egészségügybe több tényező is megnehezíti. Például a világhálón szabadon fellelhető egészségügyi információ megbízhatatlan minőségú, sokszor ellenőrizhetetlen forrásból származik, reklámcélú, nemritkán kifejezetten káros [10-12]. Emellett a meglévő technikai háttér és elvi igény ellenére meglepően ritkán kerülnek ténylegesen alkalmazásra az online kommunikációs eszközök az ellátásban. Például Hollandiában már egy 2013-as felmérés szerint is a háziorvosi praxisok 91\%-a lehetôséget nyújtott online kapcsolatfelvételre, kommunikációra [13], ugyanakkor egy szintén holland, 2015-ös kutatás szerint csak a betegek 2,9\%-a kereste egészségügyi kérdéssel háziorvosát az elmúlt egy évben e-mailben vagy weboldalon keresztül [14]. A lehetőségek, igények és elvárások összehangolását elősegíti, ha ismerjük a betegek preferenciáit az infokommunikációs eszközök egészségügyi célú használatát illetően, melyeket számos tényező befolyásol [15].

Rendelőnkben kérdőívek segítségével átfogó felmérést végeztünk az orvosi vizsgálatra megjelent betegek körében, hogy megismerjük az aktuális egészségügyi problémával küzdő és személyes orvos-beteg találkozáson részt vevő betegek preferenciáit az egészségügyi célú internethasználat vonatkozásában. Az ezzel a kérdéssel kapcsolatos korábbi kutatások inkább mélységi betekintést adtak egy szúkebb szegmensbe [16], illetve nem egészségügyi ellátás során zajlottak, főleg online kiküldött kérdőívek segítségével történtek [17]; ezek az internetet eleve aktívan használók szokásait reprezentálják, ezáltal kevésbé tükrözik az egészségügyi szolgáltatásokat ténylegesen igénybe vevők szokásait, attitűdjeit. Felmérésünk ebból a szempontból pontosabb képet tud adni az aktuális betegpreferenciák terén.

\section{Betegek és módszer}

Vizsgálatunkat 2016. október és 2017. április közötti időszakban Budapesten, fül-orr-gégészeti magánrendelőnkben végeztük. Felmérésünkbe az általános fül-orrgégészeti vagy szubspeciális rendelésen (fonátria, otoneurológia, allergológia) megjelent, nagykorú betegeket vontuk be. A pácienseket önkéntes alapon anonim, a beazonosításukra nem alkalmas, illetve a betegségükre vonatkozó információkat nem tartalmazó, 20 kérdésből álló kérdőív kitöltésére kértük. A kitöltött dokumentumokat zárt urnában gyưjtöttük össze. A kérdőívek átadását és összegyưjtését a recepción dolgozó asszisztensnők végezték. Kizárólag azokat a kérdőíveket dolgoztuk fel, és azok kerültek be az értékelésbe, amelyeket hiánytalanul töltöttek ki. A papíralapú kérdőíveket Microsoft Excel 2016-os programban (Microsoft Corporation, Redmond, WA, Amerikai Egyesült Államok [USA]) digitalizáltuk és összesítettük.

A kérdőív kérdéseit a Mellékletben összesítettük, melyben megjelölésre kerültek a betegek demográfiai adatai. Az adatgyưjtés tartalmazta, hogy a páciensek milyen eszköz segítségével és milyen gyakorisággal használják a világhálót. Megvizsgáltuk betegeinknek az egészségügyi információk szerzésével kapcsolatos szokásait, milyen rendszerességgel keresnek az interneten egészségügyi tartalomra, azzal mennyire vannak megelégedve, és megítélésük szerint mennyire sikerült megérteni az ott olvasottakat. Kíváncsiak voltunk a páciensek nyitottságára a kezelőorvosuk által ajánlott egészségügyi weboldalak olvasásával kapcsolatosan. Kérdéseink kiterjedtek a páciensek orvosválasztásra vonatkozó szokásaira és a kezelőorvosukkal történő kapcsolattartás formáira is, azaz melyik kommunikációs csatornákat részesítik előnyben, kommunikáltak-e korábban online formában orvossal, és azzal mennyire voltak elégedettek. Megkérdeztük azt is, hogy miként ítélik meg az online kommunikáció hatását az egészségi állapotukra, és hogy ezt a kommunikációs formát mennyire ítélik biztonságosnak. Rákérdeztünk egészségügyi alkalmazások, internetalapú eszközök ismeretére, használati gyakoriságára és az azokról alkotott véleményekre. Felmértük, betegeink mennyire aktívak az egészségügyi információ internet útján történő átadásában betegtársaik körében.

\section{Eredmények}

A 221 megkérdezett páciens közül 208 fő adott le hiánytalanul kitöltött kérdőívet. A válaszadók közül 63,5\% nő és 36,5\% férfi. A páciensek többsége, 113 fó $(54,3 \%)$ 30-44 éves korú, 53 fó $(25,5 \%)$ 45-64 éves, 26 fó (12,5\% 18-29 éves, és 16 fó $(7,7 \%) 65$ év fölötti. Az egyes korcsoportokban megjelenő elemszámok hetero- 
1. Ön milyen nemú? (a: nő, b: férfi)

2. Az Ön életkora: (a: 18-29 év, b: 30-44 év, c: 45-64 év, d: 65 év felett)

3. Ön milyen gyakran használja az internetet? (a: naponta, b: párszor egy héten, c: párszor havonta, d: egyáltalán nem)

4. Ön milyen eszköz segítségével internetezik a leggyakrabban? (a: okostelefon, b: tablet, c: laptop, d: asztali gép, e: egyéb)

5. Ön milyen gyakran használja az internetet egészségügyi információ szerzésére? (a: naponta, b: hetente többször, c: hetente, d: havonta párszor, e: egyáltalán nem)

6. Ön milyen gyakran részesíti előnyben az online egészségügyi információ-szerzést, ahelyett hogy személyesen orvoshoz fordulna? (a: rendszeresen, b: előfordult már, c: soha, először orvoshoz megyek, d: először orvoshoz megyek)

7. Ön mennyire elégedett az interneten olvasott egészségügyi információk színvonalával, hitelességével? (a: tökéletesen elégedett vagyok, b: többnyire elégedett, c: közepesen, d: kevésbé vagyok elégedett, e: elégedetlen vagyok)

8. Ön saját megítélése szerint mennyire érti meg az online olvasott egészségügyi információkat? (a: teljes mértékben megértem, b: többnyire értem, c: közepesen értem, d: kevésbé értem, e: általában nem értem)

9. Ön szívesen olvasna a kezelőorvosa által ajánlott egészségügyi témájú weboldalakat? (a: igen, b: nem, c: nem tudom)

10. Ön a kezelőorvosával folytatott konzultációban melyik kommunikációs csatornát tartja a legfontosabbnak? (a: személyes találkozás, b: e-mail, c: SMS, d: chat, e: webkamera)

11. Korábban volt-e rá példa, hogy kezelőorvosával online kommunikált egészségügyi állapotával, gyógykezelésével, kivizsgálásával kapcsolatban? (a: igen, b: nem)

12. Ha az előző kérdésre igennel felelt, Ön mennyire volt elégedett a kezelőorvosával történő online kapcsolattartás hatékonyságával? (a: maximálisan elégedett, b: többnyire elégedett, c: közepesen, d: kevésbé voltam elégedett, e: elégedetlen voltam)

13. Ön mennyire tartja biztonságosnak az online kommunikációt kezelőorvosával? (a: tökéletesen biztonságosnak tartom, b: többnyire, c: közepesen, d: kevésbé, e: egyáltalán nem biztonságos)

14. Ön szerint az Ön egészségügyi állapotára, gondozására, kezelésére pozitív hatással lenne, ha kezelőorvosával online kommunikáció rendelkezésre állna? (a: teljes mértékben, b: többnyire, c: nem, d: nem tudom)

15. Ön használ-e valamilyen egészséggel kapcsolatos alkalmazást (applikációt)? (a: rendszeresen, b: előfordult már, c: nem, d: nem tudom, $\mathrm{mi} \mathrm{az}$ )

16. Ön rendszeresen regisztrálja-e, méri-e valamelyik egészségi paraméterét internet segítségével kommunikáló eszközzel? (a: rendszeresen, b: előfordult már, c: nem, d: nem érdekel)

17. Ön szívesen használna-e a jövőben olyan alkalmazást, amely által lehetősége van egészségi paramétereinek regisztrálására, tárolására, kezelőorvosához történő továbbítására? (a: igen, b: nem, c: nem tudom)

18. Ön milyen gyakran választ kezelőorvost a világhálón keresztül? (a: rendszeresen, b: előfordult már, c: soha)

19. Ön milyen gyakran osztja meg tapasztalatait az interneten keresztül betegtársaival? (a: rendszeresen, b: előfordult már, c: nem jellemző)

20. Ön szerint az internet helyettesíti a személyes, fizikai jelenlétet? (a: igen, b: nem)

A melléklet celláiban a kérdőívben megjelenő kérdéseket és zárójelben, pontokba szedve a válaszlehetőségeket tüntettük fel.

genitása és az ebből adódó nem reprezentatív minta miatt a további eredmények elemzése során eltekintettünk ezen csoportok statisztikai összehasonlító elemzésétől.

A megkérdezettek 93,8\%-a naponta használja a világhálót, 4,8\% párszor hetente, míg 1,4\% párszor havonta. A betegek 51,4\%-a használ okostelefont internetezésre, 33,2\%-a laptopot, 28,8\%-a asztali számítógépet, 14,9\%-a tabletet (1.ábra). A 18-29 évesek között a legmagasabb az okostelefon-használók aránya $(69,2 \%)$, míg a 65 évnél idősebbek csoportjában a legmagasabb $(43,8 \%)$ az asztali számítógép-használat aránya. Egészségügyi információszerzés céljából 10,6\% naponta, 27,9\% hetente, 30,3\% havonta, 29,8\% valaha használta már az internetet, 1,4\% pedig még sohasem (2. ábra). A páciensek 19,2\%-a rendszeresen először az internethez fordul egészségügyi információért, 66,8\% esetében „előfordult már”, 14\% esetében pedig soha nem volt erre példa. A páciensek 2,4\%-a tökéletesen elégedett az online információ minő- ségével kapcsolatban, 51\% szerint többnyire, 37,5\% szerint közepesen, 8,2\% szerint kevésbé megfelelő, míg 0,9\% elégedetlen. A 18-29 éves korosztályban a legalacsonyabb az elégedettségi szint. A betegek 18,7\%-a teljesen megérti az olvasottakat, 65,9\%-a többnyire, 12,5\%-a közepesen, 2,4\%-a kevésbé, 0,5\%-a egyáltalán nem érti meg. A betegek 73,6\%-a szívesen olvasna kezelőorvosa által ajánlott egészségügyi weboldalakat, míg 7,7\% nem, $16,9 \%$ pedig nem tudja (3. ábra). Az ,igen”-nel válaszolók között női dominancia látható (nők: $80 \%$, férfiak: 61,8\%), míg a „nem tudom”-mal felelők között férfitúlsúly figyelhető meg (nők: 13\%, férfiak: 25\%).

A páciensek 95,2\%-a a személyes kapcsolattartást tartja a legfontosabbnak, de a betegek $47,6 \%$-a emellett a telefonon keresztüli, 27,4\%-a pedig az e-mailben való kommunikációt is ugyanolyan fontosnak jelölte. Az SMS, a webkamera és a chat csak szórványosan jelenik meg a válaszok értékelése során, mindösszesen a betegek 7,2\%- 


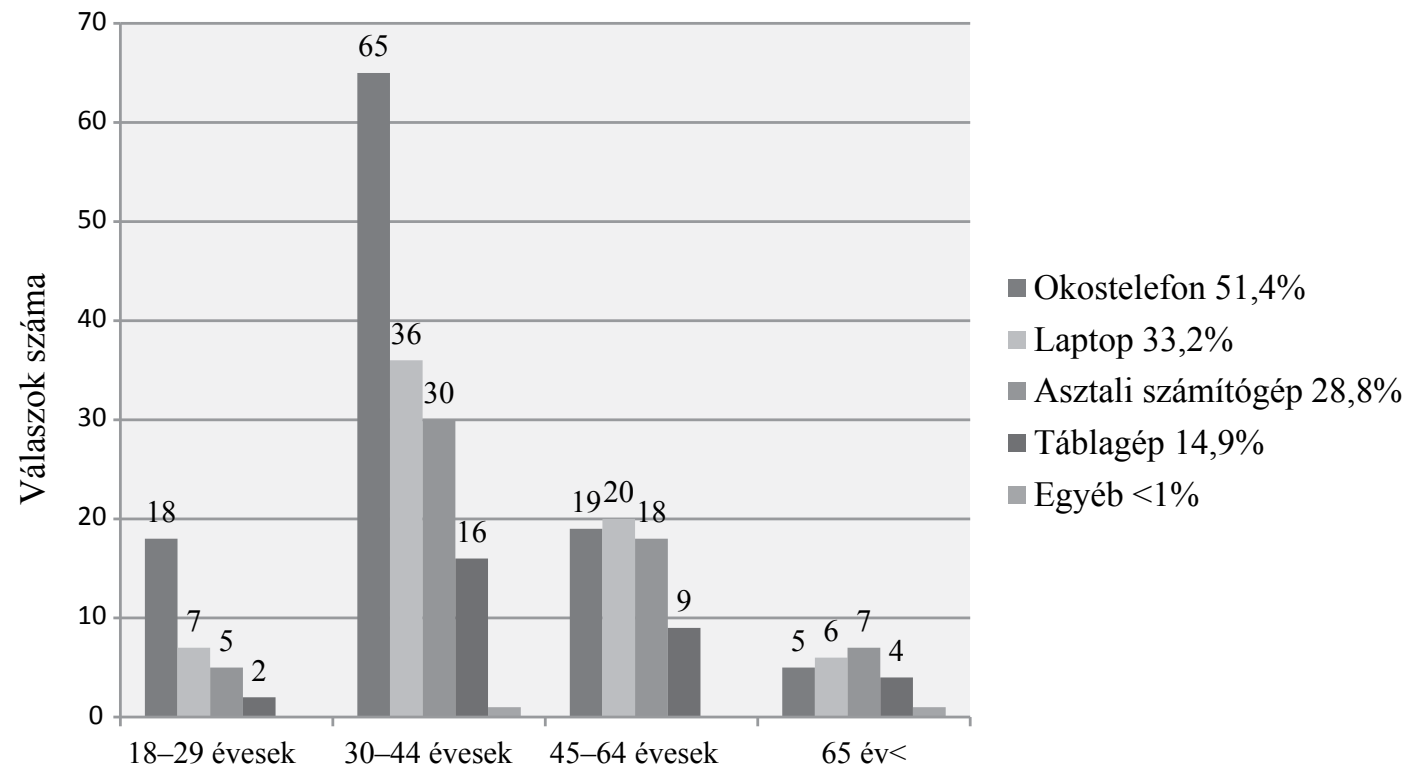

Az egyes hasábok a vizsgált korcsoportokat mutatják.

ánál (4. ábra). A megkérdezett betegek 31,7\%-a már kommunikált online kezelőorvosával. Azok között a páciensek között, akik már folytattak online kommunikációt kezelőorvosukkal, 61,8\% teljesen elégedettnek bizonyult, 30,9\% többnyire elégedettnek vallotta magát, 7,3\% kevésbé. A betegek 35,6\%-a tökéletesen biztonságosnak tartja az online kommunikációt a kezelőorvossal, $38,5 \%$ többnyire biztonságosnak ítéli, azaz összesen $74,1 \%$ mutat bizalmat az online kommunikációval kapcsolatban. A megkérdezettek 30,3\%-a szerint egészségi állapotukra, gondozásukra, kezelésükre egyértelmúen pozitív hatással lenne, ha kezelőorvosukkal online kommunikálhatnának, 42,3\% véleménye szerint „többnyire igen”, tehát 72,6\% pozitív hatást várna. A nők jellemzően nagyobb arányban elégedettek.



2. ábra

| Az egészségügyi célú internethasználat gyakorisága
A betegek 7,7\%-a rendszeresen használ egészségügyi alkalmazást okostelefonon, $24,1 \%$ esetében már előfordult, $66,8 \%$ viszont nem használ, míg $1,4 \%$ nem tud ilyen lehetőségről, az utóbbiak mind nőnemúek ( 3 fö, $1,4 \%)$. Az életkor előrehaladásával nő az egészségügyi alkalmazást nem használók aránya (46-61-84-75\%). A megkérdezettek 75\%-a még sohasem regisztrálta egészségi paramétereit internettel kommunikáló eszközön, míg $16,3 \%$ valaha használt, $6,3 \%$ pedig rendszeresen használ internetet; a betegek 2,4\%-a nem mutat érdeklődést ez iránt. A férfiak ritkábban vagy nem használnak ilyen termékeket, ugyanakkor a páciensek 52,9\%-a nyitottnak mutatkozik kipróbálásuk iránt, 27,9\% elutasítja és 19,2\% bizonytalan. A legmagasabb a 18-29 éves korcsoportban (69\%) az érdeklődők aránya.

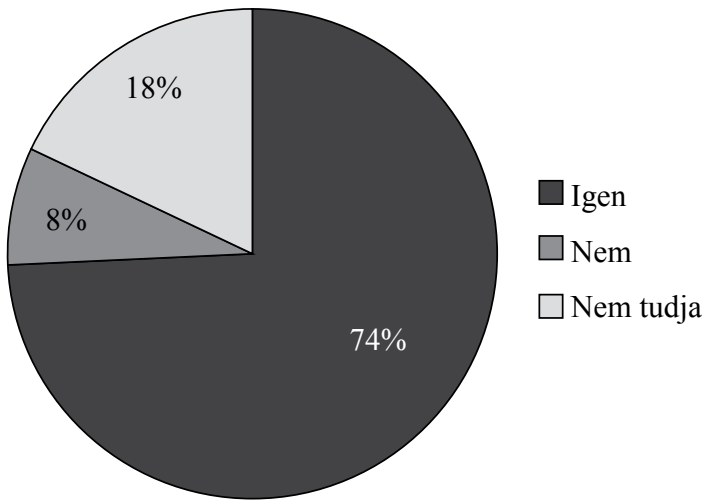

3. ábra Az „Ön olvasna-e kezelöorvosa által ajánlott egészségügyi weboldalakat?” kérdésre adott válaszok grafikus összesítése 


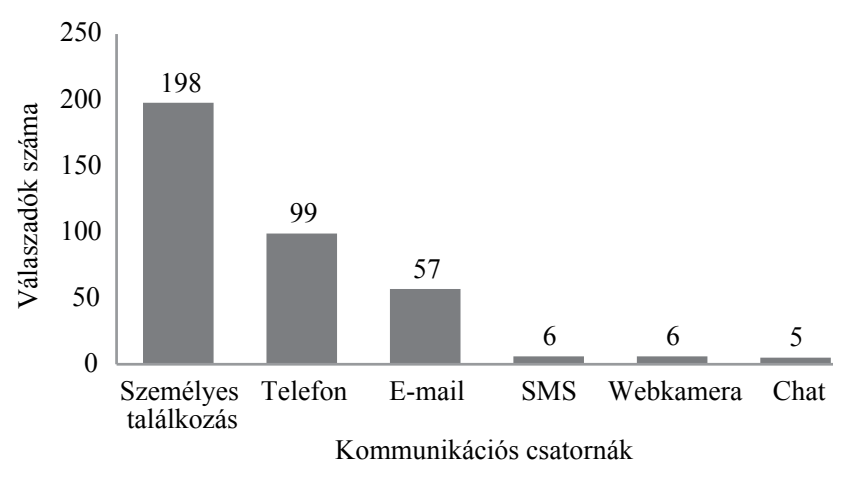

4. ábra |Az orvosi konzultációban preferált kommunikációs csatornák

A páciensek 16,8\%-a rendszeresen az internet segítségével választja ki kezelőorvosát, $60,1 \%$ esetében már előfordult ilyen, 23,1\%-nál még soha nem volt rá példa (5. $a ́ b r a)$. Mindkét nem esetében kiegyensúlyozottan $60 \%$ körül van azok aránya, akiknél „előfordult már” az interneten történő orvosválasztás. A betegek 3,4\%-a rendszeresen osztja meg tapasztalatait a világhálón keresztül betegtársaival, 14,4\% esetében előfordult már ilyen, míg 82,2\%-nál „nem jellemző”. A válaszadók egyértelmú többsége szerint $(96 \%)$ az internet nem helyettesíti a személyes találkozást, a vizsgálatot.

\section{Megbeszélés}

Az általános nethasználati szokásokat illetően felmérésünk is igazolta, hogy az internet gyakorlatilag az életünk részévé vált. Betegeink 93\%-a naponta csatlakozik a világhálóra, jelentős növekedést tapasztalva a 2014-ben Tóth és mtsai által mért 60\%-hoz képest [17]. Az internetelérésre használt eszközök tekintetében jól látható a trend a mobileszközök, elsősorban a telefon irányában. Pácienseink több mint fele internetezik a mobilján, közel harmaduk használ táblagépet, és szintén csak harmaduk asztali gépet. Az elsó év 2016 volt, amikor világszerte először haladta meg a mobilon és tableten internetezők száma a csak asztali gépet használókét [18]. Az okostele-

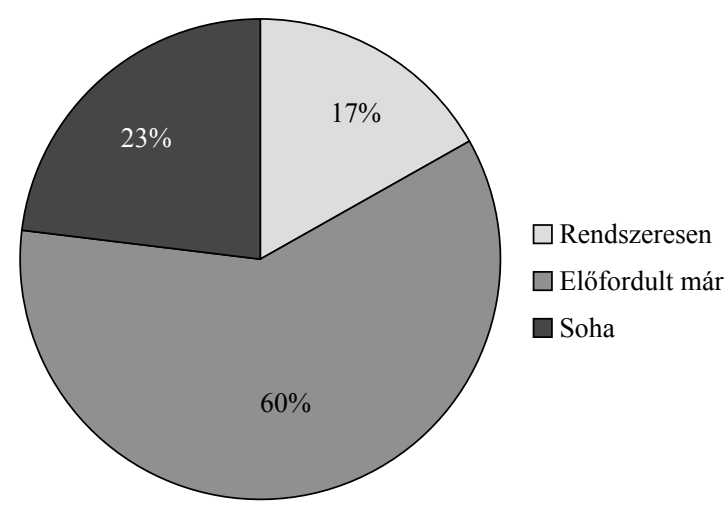

5. ábra

$\mathrm{Az}$ „Ön milyen gyakran választ kezelőorvost a világhálón keresztül?” kérdésre adott válaszok grafikus összesítése fonok térhódítása nem véletlen: ma már kedvező áron elérhetők, teljesítmény szempontjából felveszik a versenyt a valódi számítógépekkel, az információhoz történó azonnali hozzáférés lehetőségével pedig előnyt kínálnak az élet számos területén, ezenkivül fontos feltúnési és önkifejezési eszközzé váltak. A mobileszközök elsődlegessége felhívja a figyelmet, hogy az egészségügyi információforrások létrehozása során ügyelni kell arra, hogy az elérhető tartalmak okostelefonokon is jól olvashatók legyenek, és a honlapok kezelhetőségét is ennek megfelelően érdemes kialakítani.

Az általunk megkérdezettek közül szinte minden beteg használta már az internetet egészségügyi információ szerzésére. Kétharmaduk alkalomszerúen, közel ötödük rendszeresen tájékozódik az internetről egészségügyi problémájával kapcsolatban, mielőtt orvoshoz fordulna, ami trendszinten megfelel a nemzetközi tapasztalatoknak. Az amerikaiak 80\%-a használja az internetet egészségügyi információ szerzésére, 35\%-uk pedig diagnózist is felállított már ez alapján [19-21]. Érdemes megemlíteni, hogy egy 2012-es hazai felmérés szerint bár az orvosok nyitottsága egyre nagyobb, mégis több mint a háromnegyedük nem tartja egyértelmúen helyesnek a betegek internetről való tájékozódását, elsősorban szakmai okokból, másrészt az orvos-beteg kapcsolat megváltozásától tartva [22]. Az interneten olvasott egészségügyi információk színvonalával pácienseink közel fele többnyire elégedett, míg egy $201 \mathrm{l}$-es angol kutatásban a válaszadók 69\%-a jónak vagy kiválónak, 89\%-uk az átlagostól a kiválóig értékelte az olvasottakat [23]. Felmérésünk szerint azonban érdekes módon a fiatalabb generáció szkeptikusabb az idősebbekhez képest. Ez talán annak tudható be, hogy az internetes érában felnőttek jobban tisztában vannak azzal a ténnyel, hogy az interneten fellelhetó információ megbízhatósága sok esetben kérdéses, amiről egy összefoglaló közleményünkben mi is beszámoltunk nemrég [10]. Vizsgálatunk során ugyanakkor az is kiderült, hogy a betegek közel háromnegyede nyitottságot és bizalmat mutat az online egészségügyi tartalmak iránt, ha azt a kezelőorvosa ajánlja. Ugyanez a fenti angol kutatásban a megkérdezettek $58 \%$-ánál volt elmondható [23]. Ez a nyitottság segíthet, hogy a személyes orvos-beteg találkozások során jóval megbízhatóbb felvilágosító célú weboldalakra terelhetjük a pácienseket. Ráadásul ezt a hatást maguk a betegek tovább fokozhatják a közösségi oldalakon való további megosztások révén, emellett pedig egy lehetőség is, hogy direkt javítsuk az úgynevezett $e$-health literacy-t, azaz a betegek képességét a hatékonyabb egészségügyi célú internethasználatra.

Felmérésünk során kiemelten vizsgáltuk betegeink szokásait és igényeit az online orvos-beteg kommunikáció terén. Eredményeink azt mutatják, hogy kisebbségben vannak azok, akik kezelőorvosukkal már online is kommunikáltak, azonban komoly igény mutatkozik rá, főleg a fiatalabbak körében. A fenti angol felmérésben is csak a betegek 8\%-a élt az e-mail-kommunikáció lehető- 
ségével, ugyanakkor a megkérdezettek $50 \%$-a jelezte ez iránti nyitottságát [23]. Azok a betegek, akik már kerültek digitális kapcsolatba orvossal, kifejezetten elégedettek voltak ezzel a kommunikációs formával, ráadásul a megkérdezettek közel háromnegyede úgy véli, egészségi állapotára is pozitív hatással lenne, ha kezelőorvosával online is érintkezhetne. Ez az igény és pozitív attitúd jelzi, hogy érdemes lenne mélyebben implementálni az online kommunikációt orvosi oldalról is, mivel az növelné a betegek megelégedettségét, de akár a kezelés hatékonyságát is [23]. Természetesen nem szabad figyelmen kívül hagyni, hogy a magyar egészségügyben ez nincs beépítve a munkaidőbe, és sok esetben az infrastruktúra sem kifejezetten alkalmas rá. Ráadásul a betegekkel meg kell értetnünk, hogy ismeretlenül, e-mailben való megkeresés során az orvos nem állíthat fel távdiagnózist. Ezzel együtt - bizonyos korlátok között - az orvos által már kezelt beteggel való online kapcsolattartás számos előnnyel bír a hazánkban egyébként lényegében teljesen elfogadott telefonos konzultációval szemben. Ugyanakkor felmérésünk azt is igazolta, hogy a betegek jobban bíznak a telefonos érintkezésben, mint az internetes üzenetváltásban, és lényegében minden megkérdezett egyetértett azzal, hogy az online kommunikáció nem helyettesíti az orvossal történő személyes találkozást. Az egészségügyi jellegü okostelefon-alkalmazások terén Magyarországon nem érezni igazi áttörést, a Tóth és munkacsoportja által 2014-ben végzett felméréshez képest csak kismértékű penetrációnövekedést tapasztaltunk a betegek körében [17]. Ebben nem követjük a hazánkhoz képest jobban digitalizált egészségüggyel rendelkező országokat, ahol egyértelmúen jóval nagyobb arányban használnak ilyen applikációkat. Lehetőség van is rá, hiszen az IMS (Intercontinental Market Services) felmérése alapján már 2015-ben nagyjából 165 ezer, okostelefonon futó egészségügyi alkalmazás volt elérhető a két vezető platformon (android, iOS) [24], amelyek száma vélhető́en azóta is dinamikusan növekszik. Egy 2015-ös felmérés szerint az USA-ban az okostelefon-birtokosok több mint fele töltött már le és használt is egészségügyi applikációt, ugyanakkor a felhasználók inkább csak próbálgatják ezeket az applikációkat, de közel felük elóbbutóbb törölte az alkalmazást telefonjáról [25]. A fentiekkel szemben pozitívumként értékeltük, hogy az általunk megkérdezett betegek közel negyede használt már olyan internetalapú digitális eszközt (okosóra, okosmérleg stb.), amely valamely egészségügyi paraméter regisztrálására, nyomon követésére alkalmas. A világ fejlett országaiban már ma is széles körben elérhető számos telemedicina-eszköz, ezek gyakorlati alkalmazhatósága sok esetben mégis korlátozott a technológia kiforratlansága miatt. Az USA tagállamainak többségében és számos nyugat-európai államban már törvény szabályozza a telemedicina-alkalmazások használatát, adatkezelését és betegbiztosítás általi fedezetét [26]. Magyarországon 2016-os adatok alapján összesen 5 finanszírozott telemedicina-szolgáltatás érhetô el [27]. A telemedicina meghonosítására irányuló kísérletek eddig jellemzően szórványosak és sikertelenek voltak a hiányzó jogi szabályozás és finanszírozás miatt, 2018 tavaszán azonban elkezdődött a Szegedi Tudományegyetemen az Európai Unió támogatásával (Széchenyi 2020) a hazai telemedicina-rendszer múködési modelljének kialakítása. A jövő gyógyító munkáját jelentősen megkönnyítheti, ha egy krónikus betegség gondozása során az eddigiekhez képest nagyságrendekkel több adat áll rendelkezésre, mivel ezek nem csak az orvos-beteg találkozások alkalmával kerülnek rögzítésre, és hozzáférésük a beteg távollétében is megvalósulhat. Az általunk megkérdezett betegek több mint fele támogatná, hogy az általa használt eszköz, alkalmazás által regisztrált adatokhoz a kezelőorvosa is hozzáférjen.

Felmértük a betegek oldaláról az internetnek azt az orvosok számára új és szokatlan aspektusát is, hogy a páciensek az orvoshoz fordulás elött információt kereshetnek a világhálón a kiválasztott doktorról. Betegeink több mint háromnegyede legalább már egy alkalommal a világhálón választott orvost magának, ső́t minden hatodik beteg rendszeresen így jár el, nemzetközi viszonylatban pedig ez eléri akár az 59\%-ot [28]. A betegportálok használatának egyik legkritikusabb aspektusa az orvosok beteg általi nyilvános minősítése, amire egy 2013-ban megjelent amerikai összefoglaló közlemény világít rá [29]. Nincs kidolgozott standard a betegek elégedettségének mérésére, általában nincs lehetősége az orvosnak reflexióra, a laikus betegek hibás következtetései károsak lehetnek az orvosok és a többi beteg számára is. Jelenleg az orvosok értékelésével foglalkozó weboldalak nem optimálisak arra, hogy a beteg kiválaszthassa a legmegfelelóbb specialistát a másoktól érkezett visszajelzések alapján [28].

Kutatásunk során a nemzetközi tapasztalatokhoz képest a legnagyobb eltérést talán a betegtársakkal történő online tapasztalatcserére való igény terén mértük, amely betegeink esetében egyik korosztályban sem mutatkozik jelentősnek, miközben Nyugat-Európában és főleg az USA-ban kifejezetten gyakori [30]. Az online betegközösségek szerepe föleg a krónikus, illetve ritka betegséggel küzdők körében jelentős, ahol interneten keresztül próbálják felvenni a kapcsolatot egymással olyan személyek, akik azonos betegséggel vagy a betegséggel kapcsolatos tapasztalatokkal rendelkeznek [31]. Az online sorstársi közösség pszichés támogató ereje, könnyú hozzáférhetősége és az ott zajló tapasztalatcsere javíthatja a gyógyulási esélyeket, így valós segítséget nyújthat az egészségügyi szolgáltatóknak is.

\section{Erősségek, limitációk}

Vizsgálatunk erőssége, hogy korábban Magyarországon nem készült hasonlóan széles körü, az egészségügyi internethasználat legfontosabb aspektusait bemutató kutatás, amely orvosi szolgáltatást ténylegesen igénybe vevő betegek körében történt. Viszont a vizsgálat helyszínéül 
szolgáló intézmény elhelyezkedése és jellege (budai magánrendelő) miatt a teljes népességet illetően nem reprezentatív, és a korcsoportok egyenlőtlen elemszámeloszlása miatt statisztikai következtetések nem vonhatók le. Ugyanakkor ezeket figyelembe véve a kutatás modellként szolgálhat egy még szélesebb körü vizsgálathoz, illetve összehasonlítási alapot adhat más demográfiai jellegü betegpopulációk vizsgálatához.

\section{Következtetések}

Az egészségügyben a hagyományos, tekintélyelvü, tudásbeli aszimmetriára épülő kapcsolati modell átalakulóban van [32]. A betegek nagymértékben az interneten fellelhető információra támaszkodnak, ezért szakmai oldalról nagyobb hangsúlyt kell fektetni az ott található tartalom minőségének javítására [10]. Bár jelenleg a mindennapi orvosi tevékenységbe nincs beépítve az email mint a kapcsolattartás eszköze, valamint az internetalapú mérőeszközök alkalmazása, a sikeresebb terápia és a betegmegelégedettség fokozása érdekében célszerü lenne jobban előtérbe helyezni ezeket. A digitális technológia fejlődésének köszönhető innovációk megismerése és alkalmazása új kihívás elé állít bennünket, orvosokat, amelyeket megfelelő nyitottsággal kell a hagyományos orvos-beteg viszony értékein nyugvó tevékenységbe illeszteni.

Anyagi támogatás: A közlemény megírása, illetve a kapcsolódó kutatómunka anyagi támogatásban nem részesült.

Szerzői munkamegosztás: V. Zs.: A módszer kidolgozása, a kézirat elkészítése. H. T.: A módszer kidolgozása, a kézirat lektorálása. A cikk végleges változatát mindkét szerző elolvasta és jóváhagyta.

Érdekeltségek: A szerzőknek nincsenek érdekeltségeik.

\section{Irodalom}

[1] Weinstein RS, Lopez AM, Joseph BA, et al. Telemedicine, telehealth, and mobile health applications that work: opportunities and barriers. Am J Med. 2014; 127: 183-187.

[2] Van de Belt TH, Engelen LJ, Berben SA, et al. Internet and social media for health-related information and communication in health care: preferences of the Dutch general population. J Med Internet Res. 2013; 15: e220.

[3] Meskó B, Drobni Zs, Bényei É, et al. Digital health is a cultural transformation of traditional healthcare. mHealth 2017; 3: 38.

[4] European Commission. Digital agenda for Europe: a Europe 2020 initiative. European Commission, Brussels. Available from: www.eige.europa.eu/resources/digital_agenda_en.pdf [accessed: July 26, 2018].

[5] Bergmo TS, Kummervold PE, Gammon D, et al. Electronic patient-provider communication: will it offset office visits and telephone consultations in primary care? Int J Med Inform. 2005; 74: 705-710
[6] Louis AA, Turner T, Gretton M, et al. A systematic review of telemonitoring for the management of heart failure. Eur J Heart Fail. 2003; 5: 583-590.

[7] Martínez A, Everss E, Rojo-Alvarez JL, et al. A systematic review of the literature on home monitoring for patients with heart failure. J Telemed Telecare 2006; 12: 234-241.

[8] McGeady D, Kujala J, Ilvonen K. The impact of patient-physician web messaging on healthcare service provision. Int J Med Inform. 2008; 77: 17-23.

[9] Wallwiener M, Wallwiener CW, Kansy JK, et al. Impact of electronic messaging on the patient-physician interaction. J Telemed Telecare 2009; 15: 243-250.

[10] Horváth T, Varga Zs. Online health information: positivities, problems, solutions. [Online egészségügyi információ: pozitívumok, problémák, megoldások.] Orvostovábbk Szle. 2017; 24: 70-73. [Hungarian]

[11] Horváth T, Matics K, Meskó B. An objective scoring system to evaluate the credibility of health related websites. [Rendszer az egészségügyi weboldalak hitelesítésére.] Orv Hetil. 2018; 159: 511-519. [Hungarian]

[12] Ködmön J. Health information on the internet. [Egészségügyi információ az interneten.] Orv Hetil. 2018; 159: 855-862. [Hungarian]

[13] Krijgsman J, de Bie JD, Burghouts A, et al. eHealth, Verder dan je Denkt: eHealth Monitor 2013. Available from: https://www. nivel.nl/sites/default/files/bestanden/Rapport-ehealth-verderdan-je-denkt.pdf

[14] Huygens MW, Vermeulen J, Friele RD, et al. Internet services for communicating with the general practice: barely noticed and used by patients. Interact J Med Res. 2015; 4: e21.

[15] Or CK, Karsh BT. A systematic review of patient acceptance of consumer health information technology. J Am Med Inform Assoc. 2009; 16: 550-560.

[16] Molnár R, Sági Z, Fejes Zs, et al. How patients of an outpatient clinic look for information related to their health. [Egészségügyi információszerzés módjai szakrendelésen megjelent betegpopuláció körében.] Metszetek 2017; 6: 124-138. [Hungarian]

[17] Tóth T, Remete SG, Filep N, et al. The e-patient is a friend or an enemy? Health-related internet usage in Hungary. [E-páciens: barát vagy ellenség? Egészséggel kapcsolatos internetezési szokások Magyarországon.] IME 2014; 13: 49-54. [Hungarian]

[18] Mobile and tablet internet usage exceeds desktop for first time worldwide. Available from: http://gs.statcounter.com/press/ mobile-and-tablet-internet-usage-exceeds-desktop-for-firsttime-worldwide

[19] Prescott J, Mackie L. "You sort of go down a rabbit hole... You're just going to keep on searching": a qualitative study of searching online for pregnancy-related information during pregnancy. J Med Internet Res. 2017; 19: el94.

[20] AlGhamdi KM, Moussa NA. Internet use by the public to search for health-related information. Int J Med Inform. 2012; 81: 363-373.

[21] Fox S, Duggan M. Health online 2013. Pew Research Center. Available from: http://pewinternet.org/Reports/2013/ Health-online.aspx

[22] Győrffy Zs, Meskó B. E-physicians and e-patients in Hungary qualitative survey about physicians' internet use and attitudes toward their patients' internet use. [E-doktorok és e-páciensek Magyarországon - Kvalitatív vizsgálat a magyarországi orvosok gyógyítással kapcsolatos internethasználatáról és attitűdjeirôl.] Lege Artis Med. 2012; 22: 677-683. [Hungarian]

[23] Shaw B, Farboud A, Trinidade A, et al. Internet and e-mail use in ENT: a survey of patient usage and satisfaction. Eur Arch Otorhinolaryngol. 2012; 269: 1051-1054.

[24] IMS Institute. Patient Adoption of mHealth. Available from: https://www.iqvia.com/-/media/iqvia/pdfs/institute-reports $/$ patient-adoption-of-mhealth.pdf?la=en\&hash=B3ACFA8 
ADDB143F29EAC0C33D533BC5D7AABD689 [accessed: July 26,2018$]$.

[25] Krebs P, Duncan DT. Health app use among US mobile phone owners: a national survey. JMIR Mhealth Uhealth 2015; 3: el01.

[26] Ohannessian R, Yaghobian S. Financing telemedicine in France: a descriptive retrospective study. J Int Soc Telemed eHealth 2017; 5: e35.

[27] Bokor D. The present and future of telemedicine. [A telemedicina jelene és jövője.] Medical Tribune 2016; 5. Available from: http://medicalonline.hu/informatika/cikk/a_telemedicina_jelene_es_jovoje [Hungarian]

[28] Speer G. Searching for doctors in an unconventional manner. [Orvoskeresés hagyománytörő módon.] Available from: http:// otszonline.hu/e_medicina/cikk/orvoskereses_hagyomanytoro_ modon [Hungarian]

[29] Emmert M, Sander U, Pisch F. Eight questions about physicianrating websites: a systematic review. J Med Internet Res. 2013; 15: e24.
[30] Nath C, Huh J, Adupa AK, et al. Website sharing in online health communities: a descriptive analysis. J Med Internet Res. 2016; 18: ell.

[31] Fox S, Purcell K. Chronic disease and the Internet. Available from: http://www.pewinternet.org/2010/03/24/chronic-disease-and-the-internet/

[32] Málovics É, Vajda B, Kuba P. Paternalism or shared decision making? Patients about physician-patient communication. In: Hetesi E, Majó Z, Lukovics M. (eds.) World of services. [Paternalizmus vagy közös döntés? Páciensek az orvos-beteg kommunikációról. In: Hetesi E, Majó Z, Lukovics M. (szerk.) A szolgáltatások világa.] JATEPress, Szeged, 2009; pp. 250-264. [Hungarian]
(Horváth Tamás dr., Budapest, Rácz Aladár u. 94/G, 1121 e-mail: horvatht@gmail.com)

\title{
„In tranquillo qui libet gubernator est." (Seneca) (Hogyha elült a vihar, bárki kormányozhat.)
}

\section{Felhívás elöfizetésre}

\author{
Legyen Olvasónk a következő évben is! \\ Fizessen elő az Orvosi Hetilap 2019-es évfolyamára! \\ Egy füzet ára: $1150 \mathrm{Ft}$. \\ Éves előfizetési dij: $49900 \mathrm{Ft}$, nyugdijasoknak: $39990 \mathrm{Ft}$. \\ Az online változat éves elöfizetési dija: $29990 \mathrm{Ft}$.
}

